\title{
Conservative management of placenta previa percreta by leaving placental tissue in situ with arterial ligation and adjuvant methotrexate therapy
}

\author{
Plasenta previa perkreata'lı olgunun plasental dokunun çıkarılmadan, arter \\ ligasyonu ve adjuvan metotreksat terapisi ile konservatif yönetimi
}

\author{
Teksin Çırpan, Cem Yaşar Sanhal, Sait Yücebilgin, Serdar Özşener \\ Department of Gynecology and Obstetrics, Faculty of Medicine, Ege University, Izmir, Turkey
}

\section{Abstract}

Placenta percreta is one of the life-threatening conditions in modern obstetrics. The rising caesarean section rate means rising placenta percreta rate. Treatment strategies range from a caesarean hysterectomy to leaving the placenta in situ with or without internal iliac artery ligation/uterine artery embolisation and/or methotrexate therapy. We describe a case of placenta previa percreta which we managed successfully with conservative modalities.

(J Turkish-German Gynecol Assoc 2011; 12: 127-9)

Key words: Placenta percreta/accreta, methotrexate, conservative management

Received: 15 May, 2010

Accepted: 3 August, 2010
Özet

Plasenta perkreata modern obstetrideki hayatı tehdit eden patolojilerden biridir. Artan sezaryen doğum oranı artan plasenta perkreata oranı anlamına gelmektedir. Tedavi stratejileri sezaryen histerektomiden plasentanın içeride bırakılması veya internal iliak arter ligasyonu/uterin arter embolizasyonu ve/veya metotreksat tedavisine kadar uzanmaktadır. Bu yazıda konservatif yöntemler kullanarak başarılı sekilde yönettiğimiz bir plasenta previa perkreata tanılı olguyu takdim etmekteyiz. (J Turkish-German Gynecol Assoc 2011; 12: 127-9)

Anahtar kelimeler: Plasenta perkreata/akreata, metotreksat, konservatif yönetim

Geliş Tarihi: 15 Mayıs 2010

Kabul Tarihi: 03 Ağustos 2010

\section{Introduction}

Placenta previa is defined as a placenta implanted on the lower uterine segment and cervical ostium that prevents descent of the fetus. It is an important cause of second and third trimester vaginal bleeding. Placenta percreta is an adherence anomaly caused by the absence of both decidua basalis and Nitabuch's layer, which results in a direct attachment of chorionic villi to the myometrium. The risk of abnormal placental implantation increases with the number of previous cesarean sections (1): 4-fold after one, up to 11.3 fold after two. Furthermore, patients with a previous cesarean section and placenta previa are five times more likely to have placenta accreta or percreta. We report a case of placenta previa who had a previous cesarean section and anterior placenta percreta.

\section{Case}

A 34-year-old G2P1 woman with one previous cesarean section was diagnosed with anterior placenta previa totalis at the 38th week of gestation. Magnetic resonance imaging scan showed abnormal uterine bulging with dark intraplacental bands which were associated with myometrial invasion and also suspicious bladder invasion (Figure 1). She had undergone cesarean section electively. There were firm adhesions between the anterior part of the uterus and the bladder. The lower segment was totally adhered. An oblique incision was performed at the fundus of the uterus and a 3000 gr healthy baby was delivered. The placenta was left inside with the cord tied. The posterior branches of the internal iliac arteries were ligated bilaterally. After filling the bladder with 1000 cc physiologic saline, placental invasion was confirmed and the hysterectomy procedure were postponed. She was transfused with 1 unit of blood during the operation. In the follow up; she received methotrexate 100 mgr protocol by weekly intervals for five times (2). Her $\beta$-HCG level was 1241 $\mathrm{mIU} / \mathrm{ml}$ on day 1 of operation and $16 \mathrm{mIU} / \mathrm{ml}$ on the $60^{\text {th }}$ day. Doppler ultrasounds were performed in the postpartum 2 months period. There were no changes in the placental mass size, vascularisation, bladder invasion and the lost view of fatty planes between uterus and bladder. MRI scan showed heterogeneous signal intensity throughout the placenta. The patient underwent operation again to remove the remnant tissues. Bladder mucosa had over vascularisation but did not have any invasions. Bilateral ureteral double $\mathrm{j}$ catheters were introduced. The firm adhesions between the anterior part of the uterus and bladder were not affected by metho- 


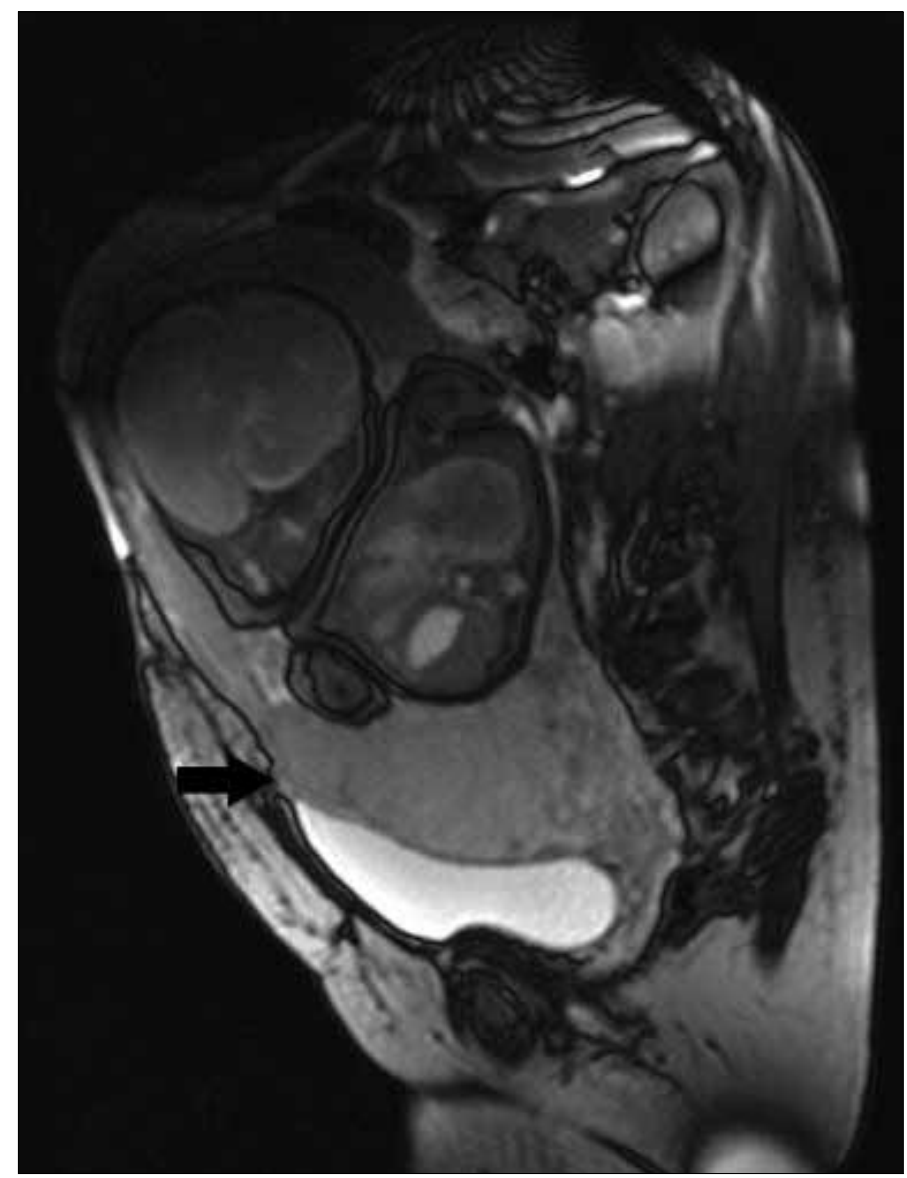

Figure 1. Abnormal uterine bulging. Sagittal T2W image of a uterus at 38 weeks gestation showing placenta previa and focal bulging of the lower uterine segment, altering the normal pear shape of the gravid uterus (arrow). The patient was proved to have placenta percreta at the time of $\mathrm{C} / \mathrm{S}$

trexate therapy, so the hysterectomy procedure could not be performed. The uterus was incised longitudinally at the fundal part and the placental mass were removed manually. 4 units of blood were also transfused. She was discharged 2 weeks later. Her regular mensturation returned 4 months after the operation. At the sixth month postparum, her $\beta$-HCG level was 0.1 $\mathrm{mIU} / \mathrm{ml}$, whereas abdominal ultrasound showed incomplete involution, with an echogenic focus in the myometrium suggestive of calcified placental remnants.

\section{Discussion}

The increasing rate of $\mathrm{C} / \mathrm{S}$ is a growing world-wide problem in modern obstetrics. Especially women, who have had a prior $\mathrm{C} / \mathrm{S}$, have the risk of facing adherence anomalies of the placenta and their complications. Placenta accreta, placenta increta and placenta percreta represent a spectrum of abnormal implantation by the placenta. Placenta percreta is the most severe of the implantation anomalies, with invasion of the myometrium and uterine serosa, often with extension into neighboring organs (3). It has been reported that placenta accreta/percreta occurs in 5\% of cases of placenta previa with unscarred uterus, rising to $25 \%$ with one previous cesarean section (4). The major risk factor for accreta is the presence of a placenta previa with a previous cesarean scar, a situation requiring hysterectomy in $66 \%$ of cases (5). Our case had had a prior $\mathrm{C} / \mathrm{S}$ and placenta previa totalis which made us suspect adherent placental tissue.

Antenatal detection success of adherence by ultrasonography and/or MRI varies between 50 and $80 \%$, but the distinction between the grades of placental invasion of the myometrium may be very difficult to discern (6). In a review by Comstock, several ultrasonographic features including the presence of placental lacunae, myometrial thickness, loss of the clear space between placenta and myometrium, and anomalies of the bladder-myometrium interface have been documented to be associated with a higher risk of placenta accreta (7). Lax et al. reported that MRI scans showing abnormal uterine bulging of the normal pear shape of the gravid uterus, heterogeneity of the signal intensity of the placenta on T2W images and the presence of T2 dark linear bands of intraplacental signal intensity have a statistically significant difference between patients with placental invasion and those with normal placentation (8). Similar findings were detected in the MRI scans of our case. It is accepted that a patient with complete placenta previa needs to be delivered by $\mathrm{C} / \mathrm{S}$. There are two major management options for placenta percreta; cesarean hysterectomy and cesarean delivery with conservative management of the placenta. Hysterectomy has long been the primary treatment for placenta accreta by ACOG (9) but it is associated with a high morbidity and mortality, including the psychological consequences of loss of the uterus in a young woman. The novel approach of treating women with placenta left in situ with methotrexate, was first reported in 1986 (10). This significantly reduces morbidity from severe haemorrhage, particularly with bladder involvement (11). Lam et al. reported a case of successful management of placenta accreta without any hysterectomy or methotrexate therapy because of the patient's strong desire to retain the uterus and side effects of the drug (12). In another case report by Crespo et. al, the patient received 4 doses of methotrexate intramuscularly every other day, alternating with 4 doses of $15 \mathrm{mg}$ folinic acid to reduce placental residual tissue which was retained in a cesarean delivery and seven months later, she passed a fleshy tissue mass vaginally then a subsequent ultrasonograhic examination documented an empty uterine cavity (13). In our case, we tried to avoid severe haemorrhage and bladder injury by leaving the placental tissue inside the uterus. We planned to perform hysterectomy but this procedure was postponed because of the placental invasions and firm adhesions. We ligated the internal iliac arteries and added methotrexate as adjuvant therapy.It decreased the level of $\beta$-hcg, but did not make any changes in placental mass or invasion so we had to perform another surgical intervention to remove placental tissue. We did not wish to perform bladder resection. We removed the placental residual mass manually with a uterine fundal incision. After the second complementary operation, she was not given any other therapy. Six months later, her regular mensturation returned and $\beta$-hcg level was 0.1 $\mathrm{IU} / \mathrm{ml}$. Ultrasonography showed a 6 week uterus and myometrial echogenic focus of calcified placental remnants. 
Selective arterial embolisation is another therapy to avoid massive obstetric haemorrhage. The procedure, however, is usually available in only a small number of tertiary centres and requires appropriately trained interventional radiologists.

\section{Conflict of interest}

No conflict of interest was declared by the authors.

\section{References}

1. Wu S, Kocherginsky M, Hibbard JU. Abnormal placentation: twenty year analysis. Am J Obstet Gynecol 2005; 192: 1458-61. [CrossRef]

2. Sherer DM, Gorelick C, Zigalo A, Sclafani S, Zinn HL, Abulafia O. Placenta previa percreta managed conservatively with methotrexate and multipl bilateral uterine artery embolizations. Ultrasound Obstet Gynecol 2007; 30: 227-8. [CrossRef]

3. Harris RD, Cho C, Wells WA. Sonography of the placenta with emphasis on pathological correlation. Semin Ultrasound CT MR 1996; 17: 66-89. [CrossRef]

4. Read JA, Cotton DB, Miller FC. Placenta accreta: changing clinical aspects and outcome. Obstet Gynecol 1980; 56: 31-4.

5. Chattopadhyay SK, Kharif H, Sherbeeni MM. Placenta praevia and accreta after previous caesarean section. Eur J Obstet Gynecol Reprod Biol 1993; 52: 151- 643. [CrossRef]
6. O'Brien JM, Barton JR, Donaldson ES. The management of placenta percreta: Conservative and operative strategies. Am J Obstet Gynecol 1996; 175: 1632-8.

7. Comstock CH, Love JJ Jr, Bronsteen RA, Lee W, Vettraino IM, Huang $\mathrm{RR}$, et al. Sonographic detection ofplacenta accreta in the second and third trimesters of pregnancy. Am J Obstet Gynecol 2004; 190: 1135-40. [CrossRef]

8. Lax A, Prince M, Mennitt KW, Schwebach JR, Budorick NE. The value of specific MRI features in the evaluation of suspected placental invasion. Magnetic Resonance Imaging 2007; 25: 87-93. [CrossRef]

9. Committee on Obstetric Practice. ACOG committee opinion Placenta accreta. Int J Gynaecol Obstet 2002; 77: 77-8

10. Arulkumaran S, Ng CS, Ingemarsson I, Ratnam SS. Medical treatment of placenta accreta with methotrexate. Acta Obstetrica Gynecologica Scandinavica 1986; 65: 285-6. [CrossRef]

11. O'Brien JM, Barton JR, Donaldson ES. The management of placenta percreta: conservative and operative strategies. American Journal of Obstetrics and Gynecology 1996; 175: 1632-8.

12. Lam H, Puna TC, Lamb PW. Successful conservative management of placenta previa accreta during cesarean section. Inter Journ of Gynecol and Obstetr 2004; 86: 31-2. [CrossRef]

13. Crespo R, Lapresta M, Madani B. Conservative treatment of placenta increta with methotrexate. International Journal of Gynecology and Obstetrics 2005; 91: 162-3. [CrossRef]

\section{Erratum}

\section{Dear Editor}

We made some mistakes on Table 4 data of article entitled ' Comparison of ovulation induction and pregnacy outcomes in IVF patients with normal ovarian reserve who underwent long protocol with recombinant-FSH and highly purified-hMG' which was published in 2011 in your Journal. If it is possible to change the related paragraph as 'In our study, the clinical pregnancy rates were 18.2 in the rec-FSH and 13.9 in the HP-hMG groups and the ongoing pregnancy rates were 15.9 and 13.9 , respectively', I will be pleasured. I would like to apologize for this error.

Best Regards, Cem Çelik 